\title{
Perspectives
}

\section{The art of medicine}

\section{Designer babies: choosing our children's genes}

The phrase "designer babies" refers to genetic interventions into pre-implantation embryos in the attempt to influence the traits the resulting children will have. At present, this is not possible, but many people are horrified by the mere thought that parents might want to choose their children's genes, especially for non-disease traits. I want to argue that the objections are usually not well articulated, and that even when they are, it's far from obvious that such interventions would be wrong.

What precisely is the objection? Of course, there are safety objections, especially ones arising from unforeseen and harmful side-effects. For example, in mice, researchers have shown that the addition of a certain gene made them better at running mazes, but also made them hyper-sensitive to pain. Such a possibility would rule out most, if not all, genetic enhancement. However, safety objections are raised by all new technologies, and do not usually instigate calls for blanket prohibition. The interesting question is, assuming genetic enhancement of the embryo is safe and effective, may such techniques ethically be used by parents?

Do the critics base their opposition on a general objection to the attempt to influence children's traits? Surely not. That is exactly what parents are supposed to do. To get our children to be healthy, well mannered, intellectually curious, and well behaved we control what they eat, have them vaccinated, teach them manners, read to them,

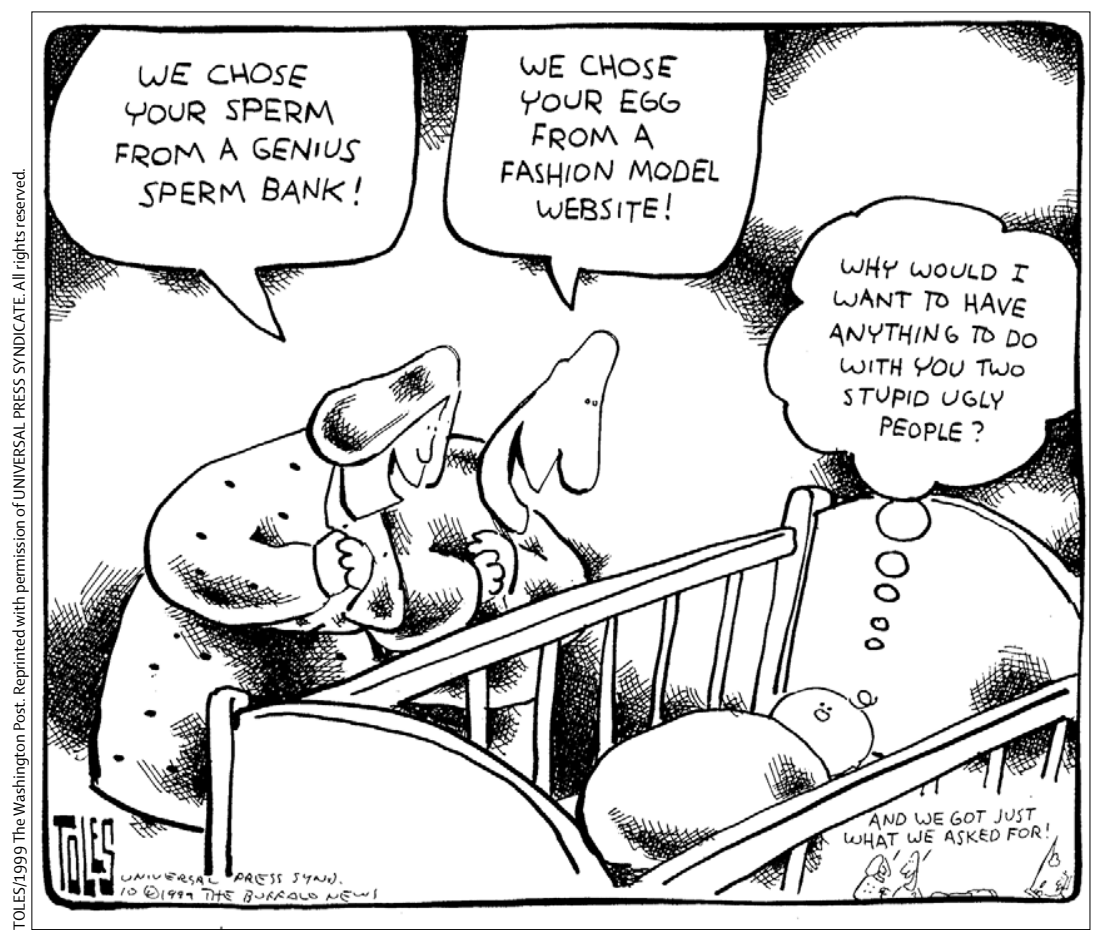

and discipline them when they misbehave. It would be absurd for a parent to say, "I never attempt to influence my children's development. I just love them for who they are." Thus, it is not influencing our children's traits that is objectionable, but rather the means to accomplish this, that is, choosing their genes. But even this has to be further refined, since just the choice of a partner-surely not morally objectionable in itself-is a way of choosing our children's genes. As Steven Pinker has put it, "Anyone who has been turned down for a date has been a victim of the human drive to exert control over half the genes of one's future children."

Perhaps the objection is not to exerting control over traits, but rather to completely determining in advance what traits one's children will or will not have. Genetic interventions, it may be thought, enable more control over what our children will be like than other modes of shaping children. If this is the objection, it embodies the "fallacy of genetic determinism", the view that our genes determine who we are and what we are like. Of course genes play a role in the traits we have, but what we are actually like is the result of multiple genes interacting with each other, and all of them interacting with the environment. In fact, even if you could choose the entire genome of a child (for example, by cloning), you would not have complete control over the child's traits. As Princeton microbiologist Lee Silver has put it, "all that anyone will ever get from the use of cloning, or any other reproductive technology, is an unpredictable son or daughter, who won't listen to his parents any more than my children will listen to me". Thus, the very term "designer babies" is a misnomer. No one will ever be able to design a child, that is, determine in advance what talents, skills, abilities, virtues, and vices the child will have.

Perhaps the objection is to the fact that the child's genes were chosen for him by his parents, thus forcing the child to have certain talents and not others. For example, it might be thought that if the child's parents picked genes associated with musical ability, their child would be forced to be a musician, when maybe he or she would rather have been an athlete. But this makes no sense. Consider a child of musicians who inherits musical ability naturally. That child may become a musician, but he or she certainly isn't forced to do so because of his genetic inheritance. Far from it; if the child doesn't practice, he won't become a musician, no matter what his genetic make-up. Admittedly, when parents choose their children's genes, they do so without the child's knowledge and consent. However, this is true of all of us, not just those who are genetically modified. None of us chooses our own genes. What is the moral significance 
in the fact that our genes were imposed on us due to someone's choice as opposed to just chance?

Some people believe that genetically modified people would have personalities, thoughts, and feelings that would be less real, less authentic than the personalities of non-modified people. But this too makes no sense, as an example will reveal. In 2003, Avshalom Caspi and colleagues reported in Science that a functional polymorphism in the promoter region of the serotonin transporter $(5-\mathrm{HTT})$ gene may be associated with a predisposition towards depression. Individuals with one or two copies of the short allele of the 5-HTT promoter polymorphism become depressed more often after stressful events than individuals homozygous for the long allele. So if you're lucky enough to have inherited two long alleles of 5-HTT, you may be more likely to be a cheerful, resilient sort of person than someone who inherited two short alleles. What if it were possible to genetically modify embryos to replace the short alleles with long ones? Would the resulting people not really be as cheerful or resilient as those who naturally inherited the long alleles? Of course not.

A more serious objection stems from the idea that people who want to choose, in advance, the traits their child will have, and are willing to spend so much money to get a child with certain traits, demonstrate a kind of desire for perfectionism that seems incompatible with being a good parent. An insistence on having a child of a certain sort, whether a musician or an athlete or a politician, amounts to parental tyranny. As Thomas Murray has put the point, "When parents attempt to shape their children's characteristics to match their preferences and expectations, such an exercise of free choice on the parents' part may constrain their child's prospects for flourishing."

An argument related to parental tyranny has been made by a member of the US President's Council on Bioethics, Michael Sandel. Sandel suggests that genetic engineering threatens what he calls the "ethic of giftedness". He argues that "To appreciate our children as gifts is to accept them as they come, not as objects of our design or products of our will or instruments of our ambition." This notion of giftedness resonates with many people, because it represents an ideal of parenting that most of us embrace. Sandel contrasts the ethic of giftedness with a style of parenting he calls "hyper-parenting", which ignores the child's own talents and abilities, and instead forces the child to do what will satisfy parental dreams and aspirations. A hyper-parent might insist that a child play sports, when he or she would rather be in the drama club, or that all the child's free time be spent in pursuit of getting into a prestigious university. We can all agree that hyperparents are obnoxious, but is there a necessary connection between hyper-parenting and interest in genetic modification of the embryo? No doubt many hyperparents would be interested in genetically modifying their

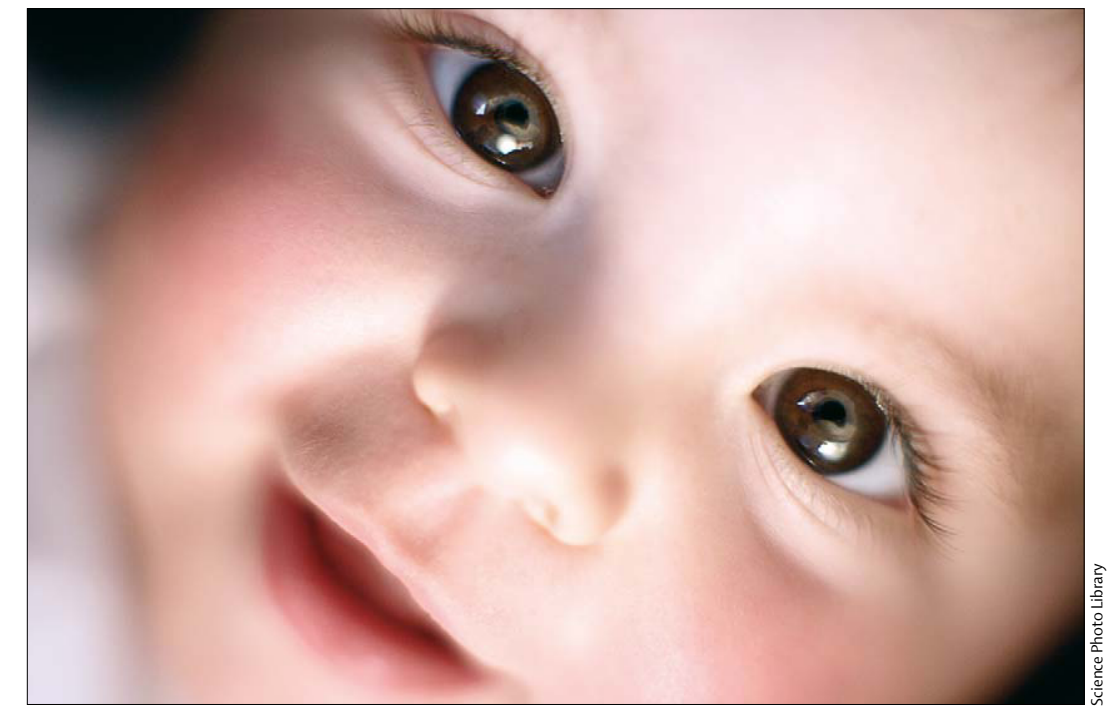

embryos, but it doesn't follow that everyone who would opt for genetic modification would be hyper-parents. That depends, I think, on the traits chosen, and the reasons for choosing them. If the traits sought were ones that could reasonably be thought to benefit the child, whatever path the child might choose, traits that would help a person flourish, traits that good parents would want to instil in their children anyway, such as kindness, generosity, compassion, or creativity, it is hard to see why choosing such traits, by genetic or conventional means, would be hyper-parenting.

A final objection to "designer children" is that this would exacerbate social differences and the gap between rich and poor. I seriously doubt that genetic interventions would have more of an influence than existing causes of inequality, such as rotten neighbourhoods and lousy schools. In any event, prebirth genetic enhancement could be used to combat social inequality, by giving children from disadvantaged backgrounds a leg up.

Genetic enhancement of embryos is, for the present, science fiction. Its opponents think that we need to ban it now, before it ever becomes a reality. What they have not provided are clear reasons to agree. Their real opposition is not to a particular means of shaping children, but rather to a certain style of parenting. Rather than fetishising the technology, the discussion should focus on which parental attitudes and modes of parenting help children to flourish. It may be that giving children "genetic edges" of certain kinds would not constrain their lives and choices, but actually make them better. That possibility should not be dismissed out of hand.

\section{Bonnie Steinbock}

Philosophy Department, University at Albany/State University of New York, Albany, NY 12222, USA

steinbock@albany.edu
Further reading

Agar N. Liberal eugenics: in defence of human enhancement. Oxford: Blackwell Publishing, 2004.

Glover J. Choosing children: genes, disability and design. Oxford: Oxford University Press, 2006.

Green RM. Babies by design: the ethics of genetic choice. New Haven: Yale University Press, 2007.

Murray TH. The worth of a child Berkeley: University of California Press, 1996.

Sandel $M$. The case against perfection: ethics in the age of genetic engineering. Cambridge: Harvard University Press, 2008 